\title{
Micrornas in autoinflammation and autoimmunity
}

\author{
Florence Apparailly \\ From 21st European Pediatric Rheumatology (PReS) Congress \\ Belgrade, Serbia. 17-21 September 2014
}

Micro(mi)RNAs are small non-coding RNAs that play critical roles in physiological networks by regulating genetic programs. They are conserved from worms to mammals and function as negative regulators of protein-encoding gene expression. Research on the role of miRNAs in pathophysiological conditions is very active since 10 years and several works evidenced that miRNAs play a key role in the regulation of immunological functions and the prevention of autoimmunity. I will discuss the involvement of miRNAs in the regulation of innate and adaptive immune functions and in the development of autoimmune disease. Focusing on the role of few miRNAs, I will emphasize the intertwined relationships between tissue homeostasis and immunity, and on how studying miRNAs in autoimmunity and immune-mediated inflammatory disorders will shed light on pathological processes and help identifying novel drug candidates and biomarkers.

\section{Disclosure of interest}

None declared.

Published: 17 September 2014

Submit your next manuscript to BioMed Central and take full advantage of:

- Convenient online submission

- Thorough peer review

- No space constraints or color figure charges

- Immediate publication on acceptance

- Inclusion in PubMed, CAS, Scopus and Google Scholar

- Research which is freely available for redistribution 